\title{
EDITORIAL
}

\section{From Utopia to Dystopia: Will the Internet Save or Destroy Democracy?}

\author{
Paul-Erik Korvela \\ University of Helsinki, FI \\ paul-erik.korvela@jyu.fi
}

Keywords: Internet; technology; social media; democracy; political participation

People often expect salvation or doom from the same source, be that some sort of divine power or technological invention, for instance. Certain innovations can be viewed as promising or threatening, depending on the viewpoint. In recent times, there has been a distinctive re-evaluation of the role of new information technology and social media for democracy. What seemed to rescue and reinvigorate democracy in the turn of the millennium is now regarded as its nemesis. How did this come about?

During the 1990s, in the early days of the Internet, the network was seen in political research as a sphere of freedom in which democratic civic debate would increase, grassroots views of individuals would surface, and new communities would emerge among like-minded people, regardless of location and nationality. The state's official policy of 'one truth' could be challenged and the abuses of those in power, big business, and the authorities could be exposed. This is in marked contrast with the current narrative of threat to democracy currently connected to the Internet and social media.

The Internet was supposed to break the state information monopoly, as well as challenge the mainstream media and provide an open democratic platform for citizens. The mainstream media could no longer hide inconvenient truths or suppress dissenting voices. The gatekeeper role of media could be diverted. Vertical power relations would have to give way to horizontal communities. The increase in citizens' discussion platforms was seen as deepening and expanding democracy and the ideal conditions for free deliberative democracy would allegedly emerge with Internet.

Today, many aspects of the Internet, such as hacking, information warfare, and the power vested in Internet platforms such as Facebook and Twitter, emerge rather as threats than salvation for democracy. The bliss of free access to information has turned into fear of false information, censorship, conspiracy theories, and hate speech. Horizontal communities of like-minded people, independent of time, place, and states, have begun to be seen as threats. It is therefore important to look critically at this change: are there grounds for past technooptimism and, on the other hand, for current technophobia?

In the early days of the Internet it was likened to uncharted territory and wild frontier by its first generation of visionaries. It was first and foremost seen as a marketplace of ideas and information, in which the libertarian ideals of freedom and equality would prevail. Anonymity 
and indifference to particularities of race, nation, religion, and so on, would mean that the new electronic frontier could create a kind of Rawlsian 'veil of ignorance' or ideal auditory for democratic citizen debate. Even though it was clear that the access to Internet was not equally distributed and skills required to use web-based systems were not good especially among the elderly or poorly educated, the Gargantuan promise of the new technology for democracy seemed to overshadow the undemocratic features and possible threats. The positive narrative related to cyber-democracy or e-democracy was passing as general currency.

Repressive governments could no longer deny information or misuse of power. Corrupt politicians could be held accountable more easily, and their lies exposed. New web-based political participation and activism would give voices to previously silenced minorities, nongovernmental organizations and dissidents. Civic society would reinvigorate as the decline of social capital would cease and civic participation only move to different arenas. Political debate could circumvent the agenda-setting of mainstream media and entrenched career politicians and parties. New communities would emerge among like-minded, regardless of the limitations of distance and place. Power relations would emerge, but they would be horizontal, autonomous, or anything but traditional.

The narrative highlighting the beneficial features of new information technology for democracy lasted until the 2010s. Still in the beginning of that decade there was a strong belief that Internet would topple down autocratic regimes, as seemed to be happening with the Arab Spring. By the middle of that decade, optimism had vanished. A number of events contributed to this eerie feeling of disenchantment, for example, the Brexit vote and Trump's election as the US President. Online campaigning and targeted political advertising made famous by the Cambridge Analytica case quickly turned the narrative into one of the ubiquitous threat: the Internet was no longer the salvation of democracy. The ideals and expectations of informed deliberative citizen debate seem to have vanished. Hate speech, trolling, and conspiracy theories have taken their place. The horizontal communities of like-minded persons have also changed from potential to threat. What seemed like a good and welcome development 20 years ago is now seen as polarization, widening of societal cleavages, and so on.

While in the early days the providers of Internet-based discussion platforms were seen as liberating us from state-controlled information, the narrative now presents those providers as manipulating our news content, selling our data to third-party partners, and working alongside with repressive governments in their attempt to curtail the free flow of information for their citizens. The worrisome narrative presents Internet users as living inside an information bubble the contents of which is controlled by opaque algorithms and companies.

At this point, a political scientist would need to look at this change in narrative with critical eye. What has actually changed? One could argue that the threats were there in the early days as well, and that the beneficial sides have not vanished anywhere. This change is mostly in the eye of the beholder. Fact-checking of politicians' speeches and electoral campaigns is much easier and quicker than before. Anti-Orwellian citizen surveillance, where the citizens keep the power elites, state officials, and big business at bay and accountable, is considerably easier now than ever before. Access to competing information channels surely helps to challenge the 'official truth'. Lowering threshold for making something public and thereby dodging the mainstream media's gatekeeping role is a fundamentally democratic development. Yet all of these also have a darker side to them, depending on the use. Technology itself is pretty much neutral, its effects on democracy depend on its use. Many of the threats associated with Internet have also existed before. For instance, people have always chosen what kind of information they want to read, and therefore have lived in a kind of Lippmannian 'pseudo-environment' also before. Manipulation, propaganda, and electoral meddling are as old as political life itself. 
The same features that seemed to better and deepen democracy in the turn of the millennium are now viewed as threatening or even ending it. Maybe this change in narrative could be explained by the change in general tenor regarding democracy. In the 1990s, the triumph of democracy seemed inevitable. The end of history was looming near and its ideological challengers had vanished right into the air. Decreasing voter turnouts and rising apathy were detectable, and in this context the Internet seemed to save democracy and invigorate it. Now, 20 years later, the general prospects of democracy in the world are rather different. Perhaps, therefore, also the narrative related to Internet is inundated with threats instead of possibilities.

In this issue of Redescriptions, Hubertus Buchstein scrutinizes the role of Otto Kirchheimer in post-war German political theory. Buchstein studies also unpublished material and shows that Kirchheimer's relation to Carl Schmitt and left-Schimittianism is not as straightforward as it is presented in previous research. In her article, Miri Rozmarin engages Judith Butler's Parting Ways in an interesting manner: Rozmarin highlights a kind of societal or relational subjectivity, or cohabitation, as a condition for critique. In her reading, critique happens within a shared space and continuous engagement with others and it should affirm its commitment to pluralization of political community. Karen Lauwers's article takes a micro-historical or micro-political approach to citizenship. She studies early twentieth-century letters by rural French people to their representatives in the parliament, and shows how the writers of those letters perceived the notions attached to their citizenship. Malte Breiding Hansen draws on Chantal Mouffe's theory of agonistic democracy and asks whether and how homonationalism can in fact be challenged by anti-gender discourse. Studying the case of Denmark, Hansen finds both of these conceptions as insufficient for agonistic public sphere.

\section{Competing Interests}

The author has no competing interests to declare.

How to cite this article: Korvela, Paul-Erik. 2021. "From Utopia to Dystopia: Will the Internet Save or Destroy Democracy?" Redescriptions: Political Thought, Conceptual History and Feminist Theory 24(1), 1-3. DOI: https://doi.org/10.33134/rds.352

\section{Submitted: 10 June 2021 Accepted: 10 June 2021 Published: 22 July 2021}

Copyright: (c) 2021 The Author(s). This is an open-access article distributed under the terms of the Creative Commons Attribution 4.0 International License (CC-BY 4.0), which permits unrestricted use, distribution, and reproduction in any medium, provided the original author and source are credited. See http://creativecommons.org/licenses/by/4.0/.

HUP Redescriptions: Political Thought, Conceptual History and

Feminist Theory is a peer-reviewed open access journal published by Helsinki University Press. 